\title{
Molecular fishing: marine oligosaccharides
}

\section{Antonio Trincone *}

Consiglio Nazionale delle Ricerche, Istituto di Chimica Biomolecolare, Pozzuoli, Italy

\section{Edited by:}

William Helbert, Centre National de la Recherche Scientifique, France

\section{Reviewed by:}

Franz Goecke, Institute of Microbiology A.S.C.R, Czech Republic

Vitor Hugo Pomin, Federal

University of Rio de Janeiro, Brazil

\section{${ }^{*}$ Correspondence:}

Antonio Trincone, Istituto di Chimica Biomolecolare, Consiglio Nazionale delle Ricerche, Via Campi Flegrei 34, 1-80078 Pozzuoli, Napoli, Italy e-mail: antonio.trincone@icb.cnr.it; antonio.trincone@gmail.com
It is difficult to overvalue the importance of polysaccharides for the great number of applicative fields in which they appeared. Oligosaccharides are relatively short compounds that are prepared from the longer polysaccharides or could also be found as such in nature. The potential in bioactivity of marine polysaccharides is still considered under-exploited and these molecules, including the derived oligosaccharides, are an extraordinary source of chemical diversity. Sustainable ways to access marine oligosaccharides are particularly important in view of the huge list of the effects they play in cell events; enzymatic tools, on which these sustainable ways are based, and modern techniques for purification and for the investigation of chemical structures, will be shortly discussed indicating the most important recent literature.

Keywords: marine oligosaccharides, marine polysaccharides, enzymatic hydrolysis, bioactivity, glycosyl hydrolases

\section{INTRODUCTION}

The long list of biotechnological applications in which polysaccharides are involved shows their importance. Especially for marine polysaccharides, the control of quality of pharmaceutical preparation based on such complex molecules is characterized by challenging aspects. Active research is welcome in this particular field (Lühn et al., 2014) for widening current limitations for use as ingredients in food supplements and cosmetics. On the other hand oligosaccharides are relatively short molecules hence it is relatively easy to establish a defined structure that can be precisely related to bioactivity, mechanism, regulation, etc. rendering them properly suitable for high standards required by pharmaceutical industry. Marine oligosaccharides are the specific topic of this perspective article.

In chemical nomenclature, the number of saccharide units for poly- to oligo- name change is not defined by a general rule being it generally extended up to 10-12 monosaccharides. However, some rhamnogalacturonans made up of 30 monosaccharides, whose NMR chemical shifts assignment was possible (Duus et al., 2000), were termed megaoligosaccharides. The limit of the smallest structure for bioactivity is not easily achievable being obviously related to specific action. However, for a case in vaccine oligosaccharides, the smallest was evidenced as a trisaccharide (Safari et al., 2008).

The potential for bioactivity of marine polysaccharides is still considered under-exploited and these molecules are an extraordinary source of chemical diversity: polysaccharides sulfates of marine origin should offer potentially safer compounds than mammalian counterparts. In the current -omic age the proposal of disseminating fucanomics and galactanomics, related to interesting sulfated fucans and sulfated galactan of marine origin was advanced (Pomin, 2012) in accord to an expected increase of research in projects of such nature. Marine oligosaccharides originate by chemical or enzymatic hydrolysis of marine polysaccharides. They have a range of important functions in biological systems, including fertilization, embryogenesis, neuronal development, cell proliferation and metastasis; thus sustainable ways to access these molecules are particularly important.

Sulfated fucans were first reported in 1913 (Kylin, 1913) while biological activity of marine polysaccharides was already known in the mid of last century (Bernardi and Springer, 1962). Modern techniques for purification and for the investigation of chemical structures will be also included in this discussion. As bioactive molecules with defined structures, low-viscosity and better solubility with respect to high molecular weight progenitors, marine oligosaccharides will be of focused interest, increasing the technology readiness level of related research and bridging the gap from basic discovery to pharmacological market application.

Related to the period 1995-2014 the hits (scientific journals, books, reference material) retrieved from Science Direct database using two search entries "marine oligosaccharides" and "marine polysaccharides" are plotted in Figure 1. Numbers are significantly high although retrieved material could contain spurious results. However, a close inspection of titles and abstracts revealed a low number of false positives. Further, a comparison with data retrieved from Pubmed resulted in the same ratio of articles for the two databases confirming the validity of the analysis.

At least two different segments can be individuated in Figure 1. The first from 1995 to 2004 in which the trends of both searches are parallel at two different values and a second segment, from the end of this period up to first 3 months of current year, in which there is an increasing difference value each year for "marine polysaccharides." Individuation of a third segment is also possible from 2009-2010 in which a sharp rise is visible for "marine polysaccharides." Values for 2014 included only first 3 months of the year. This analysis is a good starting point for this perspective article for stimulating discussion and research interests around marine carbohydrate molecules. Although the driving effect of success in glycobiology in the last decades rendered current carbohydrate synthesis techniques sufficiently advanced, 


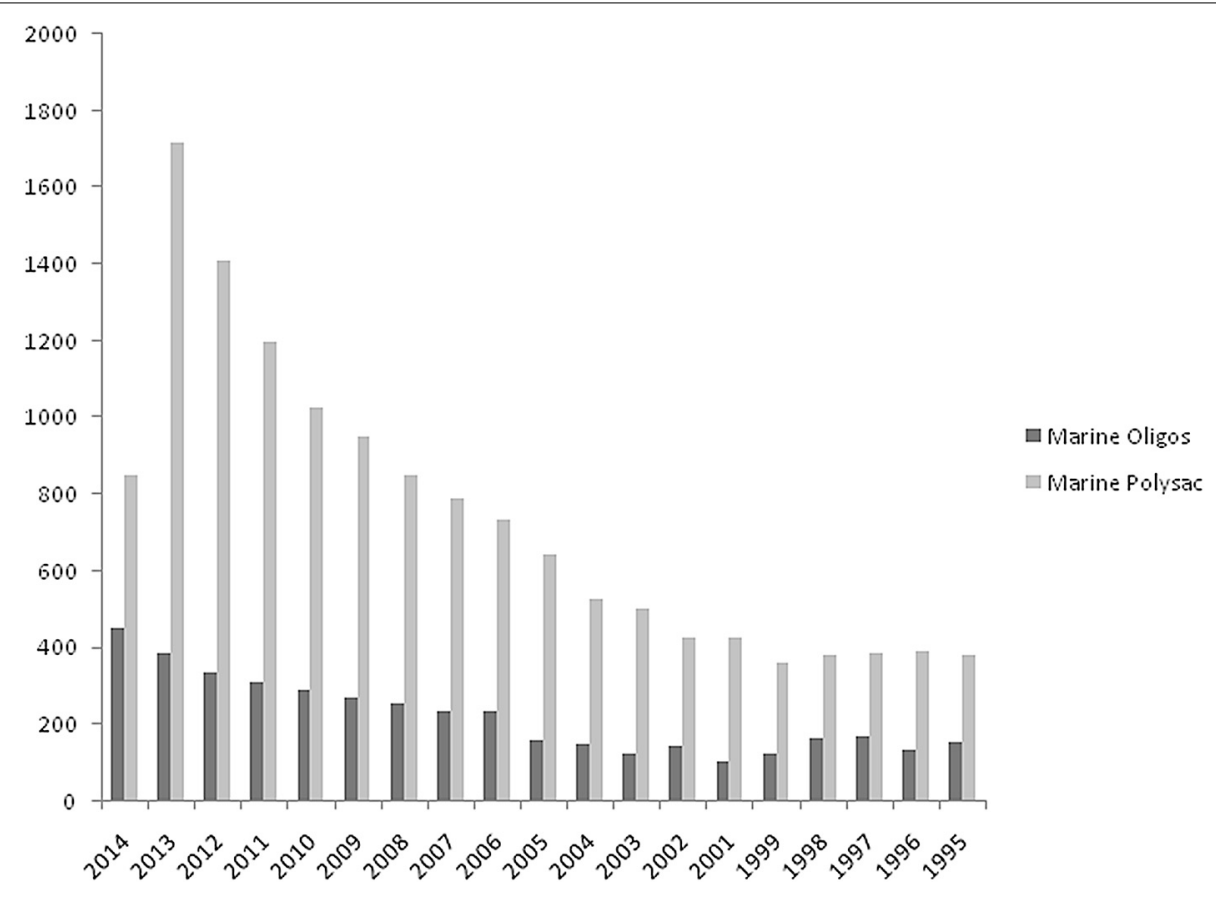

FIGURE 1 | Number of total hits searching for "marine oligosaccharides" and "marine polysaccharides" using Advanced Search feature of Science Direct a commercial database offering ca. 2500 journals and $\mathbf{2 0 , 0 0 0}$ books. Searches are conducted in all fields without double quotation marks (AND Boolean operator retrieves documents that contain both words even far apart from each other). Values for 2014 included only first 3 months of the year. Retrieval date: March, 2014. marine polysaccharides represent a convenient biological material from which marine oligosaccharides can be derived. The analysis in Figure 1 lead to a foresight for the next years related to an expected increase of studies about marine oligosaccharides (efforts for sustainable access by specific and high-yield enzymatic hydrolysis, new enabling methodologies for straightforward purification techniques, quality control, activity assay, mechanism of action, etc.).

The attracting interest in developing potential drugs for chronic diseases has been evidenced in a recent review on biofunction of marine oligosaccharides (Ji et al., 2011). The authors listed many fields for application of these molecules including food industry, cosmetics, biomedicine, agriculture, environmental protection, wastewater management, etc. However, they concluded that it is hard to explain how exactly these molecules exert their activity and future research should be directed toward the understanding of molecular level detail of activity.

\section{SOURCES}

A general view on the sources of marine polysaccharides is important. Marine organisms representing good sources of polysaccharides are numerous and include seaweed, microalgae, bacteria, animals (fish, shellfish, mollusks, etc.). Scientific knowledge present in literature for each of these sources seems to differ, from the well-known seaweed (Rinaudo, 2007) to relatively new sources of polysaccharides such as extremophiles and microalgae (de Jesus Raposo et al., 2013). The high biodiversity of the latter and how they can serve the biotechnological field has been recently pointed out (Stengel et al., 2011; Barra et al.,
2014). Cultivable or uncultivable marine microorganisms with particular emphasis on extremophiles are worth the mention. Structural characteristics, rheological properties and absence of pathogenicity of exopolysaccharides from extremophiles make these compounds considerable for food, pharmaceutical and cosmetics industries (Nicolaus et al., 2010; Satpute et al., 2010; Finore et al., 2014). The under-exploited chemical diversity present in marine polysaccharides from new sources obviously is of great interest for the development of new marine oligosaccharides.

\section{STRUCTURES}

The attention for chemical structures of oligosaccharides featured the study of structural details (ramification, substitution, etc.) even before high field NMR instruments were available. This scientific paradigm is still valid today with the increasing performances of new instruments (MS and NMR) and techniques and availability of new mild and selective methodologies for fragmentation (enzyme hydrolysis, chromatographic purification) enabling the access to homogeneous fragments that can be analyzed for their bioactivity as well (Préchoux and Helbert, 2014). In this context, unlike what could be expected, usually for oligosaccharides consisting of one type of monosaccharide unit and one glycosidic linkage, the NMR assignment of chemical shifts could be more challenging with respect to molecules variously structured (Duus et al., 2000). In general a combination of NMR and mass spectrometry is used for oligosaccharides and polysaccharides; a recent example of these studies related to galactomannan from marine fungi, reported the backbone composed by the rare $\alpha-1,2$-linked mannoses (Shoudong et al., 2014). 
The use of MS (Lang et al., 2014) and NMR techniques coupled to specific enzymes helped a lot in the structural analysis (Correc et al., 2011) and in the preparation of oligosaccharides. In an attempt to obtain low molecular-weight derivatives from sulfated fuco-oligosaccharides, results based on mild acid hydrolysis were also reported (Pomin et al., 2005). Authors were able to prepare oligosaccharides with well-defined molecular size as shown by narrow bands in polyacrylamide gel electrophoresis.

\section{ENZYMATIC HYDROLYSIS}

Enzymes for the hydrolysis of polysaccharides of marine origin are in the spotlight being the natural tools for polysaccharide metabolism in the living ecosystems. The case of chitinases is illustrative (Beier and Bertilsson, 2013). Chitin as the major component of crustacean represents a nutrient source for the ecosystem and a revised understanding of the ecology and biochemistry of this process has been proposed. The marine bacterium Saccharophagus degradans, whose complete genome sequence has been reported is of great interest in the context of enzymatic hydrolysis of polysaccharides. An unusually large number of biocatalysts degrading complex polysaccharides is reported (Weiner et al., 2008). For the sake of space it is out of the scope of this article discussing in details each polysaccharidase class. Examples of application are reported in literature (Giordano et al., 2006; Trincone, 2013) with only latest few in a not-exhaustive Table 1. However, it's worth mention a novel activity such as the marine hyaluronidase. This enzyme class is capable of hydrolysis of hyaluronic acid (HA), a biopolymer abundant in extracellular matrices. The study of hydrolysis-transfer reactions fo this enzyme is of interest for the identification of new selectivities in biocatalytic steps for the manipulation of the pharmacologically important HA. Bovine enzyme is the commercial representative of hyaluronidases but new examples are found in other environments. Venoms of two classes of fish, freshwater stingray (members of the genus Potamotrygon) and stonefish (members of the genus Synanceia), contain hyaluronidases that are considered

Table 1 | Polysaccharidases from marine environment ${ }^{a}$.

\begin{tabular}{|c|c|}
\hline Enzyme class & References \\
\hline Agarases & $\begin{array}{l}\text { Gupta et al., 2013; Liu et al., 2014; Seo et al., 2014; } \\
\text { Yang et al., } 2014\end{array}$ \\
\hline Xylanases & Chen et al., 2013 \\
\hline Chitinases & Halder et al., 2014 \\
\hline $\begin{array}{l}\kappa^{-}, \mathrm{l}-\text {, and } \lambda- \\
\text { carrageenases }\end{array}$ & Anastyuk et al., 2011; Liu et al., 2011 \\
\hline Laminarinases & $\begin{array}{l}\text { Kumagai and Ojima, 2010; Cota et al., 2011; Kim et al., } \\
\text { 2013; Kumagai et al., 2014; Menshova et al., 2014; Wu, } \\
2014\end{array}$ \\
\hline Fucanases & $\begin{array}{l}\text { Bilan et al., 2005; Descamps et al., 2006; } \\
\text { Rodriguez-Jasso et al., 2010; Silchenko et al., 2013, } \\
\text { 2014; Yu et al., 2013, 2014a,b }\end{array}$ \\
\hline Mannanases & Zahura et al., 2012 \\
\hline Hyaluronidases & Madokoro et al., 2011; Kiriake et al., 2014 \\
\hline
\end{tabular}

${ }^{a}$ Most of the examples in literature are reported in Giordano et al. (2006) and Trincone (2013), only new ones are mentioned here. spreading factors facilitating tissue diffusion of toxins by degrading hyaluronan. Natural quick action characterizing these biocatalysts is a very interesting feature for biocatalytic manipulation of these carbohydrate-related molecules (Madokoro et al., 2011; Kiriake et al., 2014) also in view of bioactivity expressed by the polymer and HA oligosaccharides (Ariyoshi et al., 2012). Another interesting case of enzyme application is the efficient food grade extraction of algae (Ecklonia cava) to prepare antioxidant watersoluble extracts (Kim et al., 2006). As far as purification technology is concerned, supercritical fluid extraction seems to be one of the most promising for economical asset also for polar compounds. It was studied at laboratory scale with theoretical mixtures and using carbohydrates produced by enzymatic transglycosylation. The process has been scaled-up to an industrial level to simulate economic feasibility and results supported the interest for a potential investment (Montanés et al., 2012).

\section{BIOACTIVITY}

As far as bioactivity of marine oligosaccharides is concerned it is evident that more and more articles are appearing in literature in recent years. Few years ago some authors summarized the bioactivity of oligosaccharides derived from seaweed in stimulating defense responses and protection against pathogens in plants. In particular seaweed oligosaccharides were able to mediate to a series of actions, such as (i) expression of genes for antifungal and antibacterial protein production, (ii) activation of other defense enzymes and (iii) production of active natural products (Weinberger et al., 2010; Vera et al., 2011), all converging toward enhanced protection against pathogens. The antioxidant activities of three types of marine oligosaccharides from alginate, chitosan and fucoidan, were investigated using several antioxidant assays with mixtures of compounds of average molecular weight of ca. $5000 \mathrm{Da}$ corresponding to 20-25 monosaccharide units, obtained by enzymatic hydrolysis of corresponding polymers. Intriguingly, the results showed that these oligosaccharides exhibited different activities in various assays (Wang et al., 2007) in relation to their structures. Attenuation of neurotoxicity induced by amyloid protein and hydrogen superoxide in human neuroblastoma cells has been reported for acidic oligosaccharide obtained from brown algae Ecklonia kurome by depolimerization. Amino and hydroxyl groups attached to free positions of the pyranoses rings can react with unstable free radicals to form stable macromolecule chelating metal ions. Alginate-derived oligosaccharides of 373-571 Da and chitooligosaccharides of 855-1671 Da obtained by enzymolysis with alginate lyase and chitosanase respectively, were investigated for cell regulation, erythrocytes haemolysis inhibition and antioxidant capacity (Hu et al., 2004). Others stressed on the anti-UV radiation potential of both alginate-derived oligosaccharides and chito-oligosaccharides and discussed the potential for development of UV radiation protector agent in the area of functional foods (He et al., 2013). Particular attention has been reserved to fucoidans for complex structures and for bioactivity they revealed. Studies to improve polymer extraction efficiency are of current interest (Rodriguez-Jasso et al., 2011) as well as those related to enzymes (Table 1) such as the fucoidanase reported from Lambis possessing endo-1,4 cleaving type action (Silchenko 
et al., 2014) that will be of interest as a tool for structure determination and for the access to specific products as also previously indicated (Pomin et al., 2005).

\section{CONCLUSION}

The intent of this short article can't be more than an indication of an important topic in marine biotechnology with (partial) signaling of key articles and individuation of possible trends as derived from global (Figure 1) and more detailed analyses of cited references. A foresight for marine oligosaccharides as molecular tools of great promise in pharmacology can be confirmed. In Europe, the research funding Horizon 2020 programme [http://ec.europa. eu/programmes/horizon2020/], with the effort to unlock potential of the sea and oceans, will result soon in knowledge increase in molecular technologies suitable for interdisciplinary study of these molecules. Resulting reports will be surely hosted in scientific journals dedicated to Marine Biotechnology.

\section{ACKNOWLEDGMENT}

The support for bibliographic search facilities is provided by Consiglio Nazionale delle Ricerche.

\section{REFERENCES}

Anastyuk, S. D., Barabanova, A. O., Correc, G., Nazarenko, E. L., Davydova, V. N., Helbert, W., et al. (2011). Analysis of structural heterogeneity of $\kappa / \beta$ carrageenan oligosaccharides from Tichocarpus crinitus by negative-ion ESI and tandem MALDI mass spectrometry. Carbohydr. Polym. 86, 546-554. doi: 10.1016/j.carbpol.2011.04.081

Ariyoshi, W., Takahashi, N., Hida, D., Knudson, C. B., and Knudson, W. (2012). Mechanisms involved in enhancement of the expression and function of aggrecanases by hyaluronan oligosaccharides. Arthritis Rheum. 64, 187-197. doi: 10.1002/art.33329

Barra, L., Chandrasekaran, R., Corato, F., and Brunet, C. (2014). The challenge of ecophysiological biodiversity for biotechnological applications of marine microalgae. Mar. Drugs 12, 1641-1675. doi:10.3390/md12031641

Beier, S., and Bertilsson, S. (2013). Bacterial chitin degradationmechanisms and ecophysiological strategies. Front. Microbiol. 4:149. doi: 10.3389/fmicb.2013.00149

Bernardi, G., and Springer, G. F. (1962). Properties of highly purified fucan. J. Biol. Chem. 237, 75-80

Bilan, M. I., Kusaykin, M. I., Grachev, A. A., Tsvetkova, E. A., Zvyagintseva, T. N., Nifantiev, N. E., et al. (2005). Effect of enzyme preparation from the marine mollusk Littorina kurila on fucoidan from the brown alga Fucus distichus. Biochemistry (Mosc) 70, 1321-1326. doi: 10.1007/s10541-005-0264-3

Chen, S., Kaufman, M. G., Miazgowicz, K. L., Bagdasarian, M., and Walker, E. D. (2013). Molecular characterization of a cold-active recombinant xylanase from Flavobacterium johnsoniae and its applicability in xylan hydrolysis. Bioresour. Technol. 128, 145-155. doi: 10.1016/j.biortech.2012.10.087

Correc, A. G., Hehemann, J. H., Czjzek, M., and Helbert, W. (2011). Structural analysis of the degradation products of porphyran digested by Zobellia galactanivorans-porphyranase. Carbohydr. Polym. 83, 277-283. doi: 10.1016/j.carbpol.2010.07.060

Cota, J., Alvarez, T. M., Citadini, A. P., Santos, C. R., de Oliveira Neto, M., Oliveira, R. R., et al. (2011). Mode of operation and low-resolution structure of a multi-domain and hyperthermophilic endo- $\beta-1,3$-glucanase from Thermotoga petrophila. Biochem. Biophys. Res. Comm. 406, 590-594. doi: 10.1016/j.bbrc.2011.02.098

de Jesus Raposo, M. F., de Morais, R. M. S. C., and de Morais, A. M. M. B. (2013). Bioactivity and applications of sulphated polysaccharides from marine microalgae. Mar. Drugs 11, 233-252. doi:10.3390/md11010233.

Descamps, V., Colin, S., Lahaye, M., Jam, M., Richard, C., Potin, P., et al. (2006). Isolation and culture of a marine bacterium degrading the sulfated fucans from marine brown algae. Mar. Biotechnol. 8, 27-39. doi: 10.1007/s10126-005$5107-0$
Duus, J. Ø., Gotfredsen, C. H., and Bock, K. (2000). Carbohydrate structural determination by NMR spectroscopy: modern methods and limitations. Chem. Rev. 100, 4589-4614. doi: 10.1021/cr990302n

Finore, I., Di Donato, P., Mastascusa,. V., Nicolaus, B., and Poli, A. (2014). Fermentation technologies for the optimization of marine microbial exopolysaccharide production. Mar. Drugs 12, 3005-3024. doi:10.3390/md12053005

Giordano, A., Andreotti, G., Tramice, A., and Trincone, A. (2006). Marine glycosyl hydrolases in the hydrolysis and synthesis of oligosaccharides. Biotechnol. J. 1, 511-530. doi: 10.1002/biot.200500036

Gupta, V., Trivedi, N., Kumar, M., Reddy, C. R. K., and Jha, B. (2013). Purification and characterization of exo- $\beta$-agarase from an endophytic marine bacterium and its catalytic potential in bioconversion of red algal cell wall polysaccharides into galactans. Biomass Bioenergy 49, 290-298. doi: 10.1016/j.biombioe.2012.12.027

Halder, S. K., Maity, C., Jana, A., Ghosh, K., Das, A., Paul, T., et al. (2014). Chitinases biosynthesis by immobilized Aeromonas hydrophila SBK1 by prawn shells valorization and application of enzyme cocktail for fungal protoplast preparation. J. Biosci. Bioengin. 117, 170-177. doi: 10.1016/j.jbiosc.2013. 07.011

He, X., Li, R., Huang, G., Hwang, H., and Jiang, X. (2013). Influence of marine oligosaccharides on the response of various biological systems to UV irradiation. J. Funct. Foods 5, 858-868. doi: 10.1016/j.jff.2013.01.035

Hu, J., Geng, M., Li, J., Xin, X., Wang, J., Tang, M., et al. (2004). Acidic oligosaccharide sugar chain, a marine-derived acidic oligosaccharide inhibits the cytotoxicity and aggregation of amyloid beta protein J. Pharmacol. Sci. 95, 248-255. doi: 10.1254/jphs.FPJ04004X

Ji, J., Wang, L.-c., Wu, H., and Luan, H. (2011). Bio-function summary of marine oligosaccharides. Int. J. Biol. 3, 74-86. doi: 10.5539/ijb.v3n1p74

Kim, E. J., Fathoni, A., Jeong, G. T., Jeong, H. D., Nam, T. J., Kong, I. S., et al. (2013). Microbacterium oxydans, a novel alginate- and laminarin-degrading bacterium for the reutilization of brown-seaweed waste. J. Environ. Manag. 130, 153-159. doi: 10.1016/j.jenvman.2013.08.064

Kim, K. N., Heo, S. J., Song, C. B., Lee, J., Heo, M.-S., Yeo, Y.-K., et al. (2006). Protective effect of Ecklonia cava enzymatic extracts on hydrogen peroxide-induced cell damage. Proc. Biochem. 41, 2393-2401. doi: 10.1016/j.procbio.2006.06.028

Kiriake, A., Madokoro, M., and Shiomi, K. (2014). Enzymatic properties and primary structures of hyaluronidases from two species of lionfish (Pterois antennata and Pterois volitans). Fish Physiol. Biochem. 40, 1043-1053. doi: $10.1007 / \mathrm{s} 10695-013-9904-5$

Kumagai, Y., and Ojima, T. (2010). Isolation and characterization of two types of $\beta$-1,3-glucanases from the common sea hare Aplysia kurodai. Comp. Biochem. Physiol. B Biochem. Mol. Biol. 155, 138-144. doi: 10.1016/j.cbpb.2009.10.013

Kumagai, Y., Satoh, T., Inoue, A., and Ojima, T. (2014). A laminaribiosehydrolyzing enzyme, AkLab, from the common sea hare Aplysia kurodai and its transglycosylation activity. Comp. Biochem. Physiol. B Biochem. Mol. Biol. 167, 1-7. doi: 10.1016/j.cbpb.2013.07.008

Kylin, H. (1913). Zur biochemie der meersalgen. Physiol. Chem. 83, 171-197

Lang, Y., Zhao, X., liu, L., and Yu, G. (2014). Applications of mass spectrometry to structural analysis of marine oligosaccharides. Mar. Drugs 12, 4005-4030. doi:10.3390/mdl2074005

Liu, G., Li, Y., Chi, Z., and Chi, Z. M. (2011). Purification and characterization of $\kappa$-carrageenase from the marine bacterium Pseudoalteromonas porphyrae for hydrolysis of $\kappa$-carrageenan. Proc. Biochem. 46, 265-271. doi: 10.1016/j.procbio.2010.08.021

Liu, N., Mao, X., Du, Z., Mu, B., and Wei, D. (2014). Cloning and characterisation of a novel neoagarotetraose-forming $\beta$-agarase, AgWH50A from Agarivorans gilvus WH0801. Carbohydr. Res. 388, 147-151. doi: 10.1016/j.carres.2014.02.019

Lühn, S., Grimm, J. C., and Alban, S. (2014). Simple and rapid quality control of sulfated glycans by a fluorescence sensor assay-exemplarily developed for the sulfated polysaccharides from red algae Delesseria sanguine. Mar. Drugs 12, 2205-2227. doi:10.3390/md12042205

Madokoro, M., Ueda, A., Kiriake, A., and Shiomi, K. (2011). Properties and cDNA cloning of a hyaluronidase from the stonefish Synanceia verrucosa venom. Toxicon 58, 285-292. doi: 10.1016/j.toxicon.2011.07.014

Menshova, R. V., Ermakova, S. P., Anastyuk,S. D., Isakov, V. V., Dubrovskaya, Y. V., Kusaykin, M. I., et al. (2014). Structure, enzymatic transformation and anticancer activity of branched high molecular weight laminaran 
from brown alga Eisenia bicyclis. Carbohydr. Polym. 99, 101-109. doi: 10.1016/j.carbpol.2013.08.037

Montanés, F., Fornari, T., Olano, A., and Ibáne, E. (2012). Isolation of prebiotic carbohydrates by supercritical fluid extraction. Scaling-up and economical feasibility. J. Chromatogr. A. 1250, 92-98. doi: 10.1016/j.chroma.2012. 04.039

Nicolaus, B., Kambourova, M., and Oner, E. T. (2010). Exopolysaccharides from extremophiles: from fundamentals to biotechnology. Environ. Technol. 31, 1145-1158. doi: 10.1080/09593330903552094

Pomin, V. H. (2012). Fucanomics and galactanomics: marine distribution, medicinal impact, conceptions, and challenges. Mar. Drugs 10, 793-811. doi: $10.3390 / \mathrm{md} 10040793$

Pomin, V. H., Valente, A. P., Pereira, M. S., and Mourão, P. A. S. (2005). Mild acid hydrolysis of sulfated fucans: a selective 2-desulfation reaction and an alternative approach for preparing tailored sulfated oligosaccharides Glycobiology 15, 1376-1385. doi:10.1093/glycob/cwj030

Préchoux, A., and Helbert, W. (2014). Preparation and detailed NMR analyses of a series of oligo- $\alpha$-carrageenans. Carbohyd. Polym. 101, 864-870 doi: 10.1016/j.carbpol.2013.10.007

Rinaudo, M. (2007). "Seaweed polysaccharides," in Comprehensive Glycoscience from Chemistry to Systems Biology Vol. 2: Analysis of Glycans; Polysaccharide Functional Properties, eds H. Kamerling (Oxford: Elsevier), 691-735

Rodriguez-Jasso, R. M., Mussatto, S. I., Pastrana, L., Aguilar, C. N., and Teixeira, J. A. (2010). Fucoidan-degrading fungal strains: screening, morphometric evaluation, and influence of medium composition. Appl. Biochem. Biotechnol. 162 2177-2188. doi: 10.1007/s12010-010-8992-2

Rodriguez-Jasso, R. M., Mussatto, S. I., Pastrana, L., Aguilar, C. N., and Teixeira, J. A. (2011). Microwave-assisted extraction of sulfated polysaccharides (fucoidan) from brown seaweed. Carbohydr. Polym. 86, 1137-1144. doi: 10.1016/j.carbpol.2011.06.006

Safari, D., Dekker, H. A. T., Joosten, J. A. F., Michalik, D., Carvalho de Souza A., Adamo, R., et al. (2008). Identification of the smallest structure capable of evoking opsonophagocytic antibodies against Streptococcus pneumoniae Type 14. Infect. Immun. 76, 4615-4623. doi: 10.1128/IAI.00472-08

Satpute, S. K., Banat, I. M., Dhakephalkar, P. K., Banpurkar, A. G., Balu, A., and Chopade, B. A. (2010). Biosurfactants, bioemulsifiers and exopolysaccharides from marine microorganisms. Biotechnol. Adv. 28, 436-450. doi: 10.1016/j.biotechadv.2010.02.006

Seo, Y. B., Lu, Y., Chi, W.-J., Park, H. R., Jeong, K. J., Hong, S.-K., et al. (2014). Heterologous expression of a newly screened $\beta$-agarase from Alteromonas $\mathrm{sp}$ GNUM1 in Escherichia coli and its application for agarose degradation. Proc. Biochem. 49, 430-436. doi: 10.1016/j.procbio.2013.12.014

Shoudong, G., Wenjun, M., Mengxia, Y., Chunqi, Z., Na, L., Jimiao, S., et al. (2014). Galactomannan with novel structure produced by the coral endophytic fungus Aspergillus ochraceus. Carbohydr. Polym. 25, 325-333. doi: 10.1016/j.carbpol.2014.01.079

Silchenko, A. S., Kusaykin, M. I., Kurilenko, V. V., Zakharenko, A. M., Isakov, V. V., Zaporozhets, T. S., et al. (2013). Hydrolysis of fucoidan by fucoidanase isolated from the marine bacterium. Formosa algae Mar. Drugs 11, 2413-2430. doi: $10.3390 / \mathrm{md} 11072413$

Silchenko, A. S., Kusaykin, M. I., Zakharenko, A. M., Menshova, R. V., Khanh, H. H. N., Dmitrenok, P. S., et al. (2014). Endo-1,4-fucoidanase from Vietnamese marine mollusk Lambis sp. which producing sulphated fucooligosaccharides. J. Mol. Cat. B Enzym. 102, 154-160. doi: 10.1016/j.molcatb.2014.02.007

Stengel, D. B., Connan, S., and Popper, Z. A. (2011). Algal chemodiversity and bioactivity: sources of natural variability and implications for commercial application. Biotechnol. Adv. 29, 483-501. doi:10.1016/j.biotechadv.2011.05.016
Trincone, A. (ed.). (2013). "Marine enzymes for biocatalysis: sources, biocatalytic characteristics and bioprocesses of marine enzymes," in Biomedicine (Cambridge: Woodhead Publishing), Series No.38. Available online at: http:// www.woodheadpublishing.com/en/book.aspx?bookID $=2822$

Vera, J., Castro, J., Gonzalez, A., and Moenne, A. (2011). Seaweed polysaccharides and derived oligosaccharides stimulate defense responses and protection against pathogens in plants. Mar. Drugs 9, 2514-2525. doi:10.3390/md9122514

Wang, P., Jiang, X., Jiang, Y., Hu, X., Mou, H., Li, M., et al. (2007). In vitro antioxidative activities of three marine oligosaccharides. Nat. Prod. Res. 21, 646-654. doi: 10.1080/14786410701371215

Weinberger, F., Guillemin, M. L., Destombe, C., Valero, M., Faugeron, S., Correa, J. A., et al. (2010). Defense evolution in the Gracilariaceae (Rhodophyta): substrate-regulated oxidation of agar oligosaccharides is more ancient than oligoagar-activated oxidative burst. J. Phycol. 46, 958-968. doi: 10.1111/j.15298817.2010.00887.x

Weiner, R. M., Taylor, L. E., Henrissat, B., Hauser, L., Land, M., Coutinho, P. M., et al. (2008). Complete genome sequence of the complex carbohydratedegrading marine bacterium, Saccharophagus degradans Strain 2-40T. PLoS Genetics 4:e1000087. doi: 10.1371/journal.pgen.1000087

Wu, S.-J. (2014). Preparation and antioxidant activity of the oligosaccharides derived from Laminaria japonica. Carbohydr. Polym. 106, 22-24. doi: 10.1016/i.carbpol.2014.01.098

Yang, M., Mao, X., Liu, N., Qiu, Y., and Xue, C. (2014). Purification and characterization of two agarases from Agarivorans albus OAY02. Proc. Biochem. 49, 905-912. doi: 10.1016/j.procbio.2014.02.015

Yu, L., Ge, L., Xue, C., Chang, Y., Zhang, C., Xu, X., et al. (2014b). Structural study of fucoidan from sea cucumber Acaudina molpadioides: A fucoidan containing novel tetrafucose repeating unit. Food Chem. 142, 197-200. doi: 10.1016/j.foodchem.2013.06.079

Yu, L., Xue, C., Chang, Y., Xu, X., Ge, L., Liu, G., et al. (2014a). Structure elucidation of fucoidan composed of a novel tetrafucose repeating unit from sea cucumber Thelenota ananas. Food Chem. 146, 113-119. doi: 10.1016/j.foodchem.2013.09.033

Yu, L., Xu, X., Xue, C., Chang, Y., Ge, L., Wang, Y., et al. (2013). Enzymatic preparation and structural determination of oligosaccharides derived from sea cucumber (Acaudina molpadioides) fucoidan. Food Chem. 139, 702-709. doi: 10.1016/j.foodchem.2013.01.055

Zahura, R. M. M., Inoue, A., and Ojima, T. (2012). Characterization of a $\beta$ D-mannosidase from a marine gastropod, Aplysia kurodai. Comp. Biochem. Physiol. B Biochem. Mol. Biol. 162, 24-33. doi: 10.1016/j.cbpb.2012.02.003

Conflict of Interest Statement: The author declares that the research was conducted in the absence of any commercial or financial relationships that could be construed as a potential conflict of interest.

Received: 03 June 2014; paper pending published: 30 June 2014; accepted: 08 July 2014; published online: 25 July 2014.

Citation: Trincone A (2014) Molecular fishing: marine oligosaccharides. Front. Mar. Sci. 1:26. doi: 10.3389/fmars.2014.00026

This article was submitted to Marine Biotechnology, a section of the journal Frontiers in Marine Science.

Copyright (c) 2014 Trincone. This is an open-access article distributed under the terms of the Creative Commons Attribution License (CC BY). The use, distribution or reproduction in other forums is permitted, provided the original author(s) or licensor are credited and that the original publication in this journal is cited, in accordance with accepted academic practice. No use, distribution or reproduction is permitted which does not comply with these terms. 